\title{
Microstructures and Properties of Nano-structural WC-12Co Coatings Deposited by AC-HVAF
}

\author{
Fan Zishuan, Wang Shansong, Zhang Zhengdong
}

University of Science and Technology Beijing, Beijing 100083, China

\begin{abstract}
WC-12Co powder with nano WC grains was used to deposit wear resistant coatings by AC-HVAF (acukote high velocity air-fuel) spray system. The phase compositions and microstructures of the coatings were examined. The microhardness, fracture toughness and wear resistance were investigated. According to the X-ray diffraction (XRD) analysis, the principal phase is WC, and its decomposition products are not found. The sprayed coating has a porosity lower than $1 \%$ and the grain sizes of coatings are among 80 100 nm which contribute to an average microhardness $\left(\mathrm{HV}_{0.3}\right)$ as high as $19403 \mathrm{MPa}$ on the surface and $17410 \mathrm{MPa}$ on the cross-section. At the load of $15 \mathrm{~N}$ and rotational speed of $1198 \mathrm{r} / \mathrm{min}$ of WC counter body, the nano-sized coatings show a decreased average mass loss by $40 \%$ compared with micro-sized coatings, and a stable friction coefficient of 0.26 0.28 (micron-sized coatings: $0.25 \sim 0.4$ ) in the dry wear conditions. It is concluded that the sprayed nano structural WC-12Co coatings have a better wear resistance.
\end{abstract}

Key words: AC-HVAF spraying; nano WC; microhardness; wear resistance

WC-Co cermet coatings are used in a wide range of wear resistant fields under various conditions which include sliding, fretting, abrasion and erosion for their good combination of high modulus, high wear resistance, and adequate fracture toughness ${ }^{[1]}$. The microstructures and properties of coatings strongly depend on the spraying method and feedstock powder. The WC-Co coatings deposited by traditional spraying methods such as air plasma spraying (APS) and high velocity oxy-fuel (HVOF) spraying have run to a bottleneck in many aspects such as higher decomposition, lower microhardness and wear-resistance. Compared to other spraying techniques, acukote high velocity air-fuel (AC-HVAF) spraying is one of the best methods for the deposition of nano WC-Co powder because of the higher velocities and lower temperatures experienced by the powder, resulting in less decomposition and decarburization of WC during spraying processes ${ }^{[2]}$.

The reduction of carbide size to the nanometer range is of great interest recently. The nano-structured WC-Co coatings usually show higher hardness and wear resistance than conventional coatings. The hardness of WC-Co increases with the decreasing of carbide size and Co content, while the fracture toughness shows an opposite tendency. According to Wang Qun's research ${ }^{[3]}$, this disappointing performance of HVOF-sprayed nano-structured coatings has been attributed to their higher tendency to decarburization, as the surface area of the nano size WC is much higher than that of their conventional micron size WC. And then the potential benefits offered by nano-scale grains have not been fulfilled ${ }^{[4]}$. One exception of improvement in preparing nano-structured WC-Co coatings was the application of HVAF (high velocity air-fuel) spraying which was characterized by lower temperature and higher velocity. Liu Shenglin ${ }^{[5]}$ studied the micron-sized WC-NiCr coatings prepared by AC-HVAF spraying, and it was found that the decarburization was minimized and coating's wear resistance was improved.

In the present research, nano WC-12Co powder with WC grain size of 50 60 $\mathrm{nm}$ and micron WC-12Co powder were used as feedstock powder and the AC-HVAF spraying was applied for coating deposition. The phases, structures, microhardness, fracture toughness and wear resistance of the prepared coatings were investigated.

Received date: April 18, 2016

Corresponding author: Fan Zishuan, Associate Professor, School of Materials Science and Engineering, University of Science and Technology Beijing, Beijing 100083, P. R. China, E-mail: fanzs5858@ 163.com 


\section{Experiment}

WC-12Co powder was manufactured by spray drying of slurries containing WC-12Co-0.4VC- $0.6 \mathrm{Cr}_{3} \mathrm{C}_{2}$ and binder, followed by reduction and carburization at $1300{ }^{\circ} \mathrm{C}$ in hydrogen atmosphere. The addition of $\mathrm{VC}$ and $\mathrm{Cr}_{3} \mathrm{C}_{2}$ played a role in inhibiting WC grain growth during processing. The diameter of the powder ranged from $15 \mu \mathrm{m}$ to $45 \mu \mathrm{m}$, and its morphology is shown in Fig.1a. Another micron-sized powder was bought from a common powder supplier, whose morphology is shown in Fig.1b. The thermal spraying process was conducted by Kermetico AC-HVAF (acukote high velocity air-fuel) spray system. The spraying parameters are listed in Table 1.

The microstructures of the coatings were observed by LEO-1450 scanning electron microscope (SEM). The porosities of the coatings were determined by a metallographical method. Microhardness measurement of the coatings was carried out 10 times for each specimen with a HXD-1000 digital microhardness tester at a load of $3 \mathrm{~N}$ and a dwell time of $15 \mathrm{~s}$. When analyzing the phase structure of the feedstock powder and sprayed coating, in order to avoid the substrate effect, the coating thickness was made up to $2 \mathrm{~mm}$ for the as-sprayed surface hardness testing. XRD analysis was done using a MAC-21 diffractometer. The coating specimens before and after wear tests were examined by SEM to analyze the wear mechanisms. Wear tests under dry friction condition were conducted using an HT-600 wear tester. The wear properties of nano-sized WC coatings were compared to those of micron-sized WC coatings which were prepared by the same HVAF spraying technique.

\section{Results and Discussion}

\subsection{Microstructure of sprayed WC-12Co coatings}

Fig.2 shows the typical cross sections of nano-structured and micron-sized WC-12Co coatings sprayed by AC-HVAF. The nano-sized coating is uniform and compact, which results from the velocity as high as $700 \sim 800 \mathrm{~m} / \mathrm{s}$ of in-flight particles and nano-sized WC grain. Its porosity is lower than $1 \%$ measured by SEM image while that of the micron-sized one is $2 \% \sim 3 \%$. The WC particles distribute homogeneously in the Co matrix. And the nano WC grain size could improve the hardness and toughness of the coating by the dispersion strengthening effect ${ }^{[6,7]}$.

\subsection{Phase composition of nano-sized WC-12Co coatings}

The XRD patterns of the WC-12Co coatings deposited by AC HVAF system are presented in Fig.3. The WC-12Co feedstock powder contains only two phases of tungsten carbide and metallic cobalt. The as-sprayed WC-12Co coating is mainly composed of $\mathrm{WC}$ and Co including very few $\mathrm{Co}_{6} \mathrm{~W}_{6} \mathrm{C}$. The AC-HVAF sprayed nano WC-12Co coatings show a very low decomposition rate. According to the Scherrer formula, calculations show that the WC grain size ranges from $80 \sim 100 \mathrm{~nm}$.

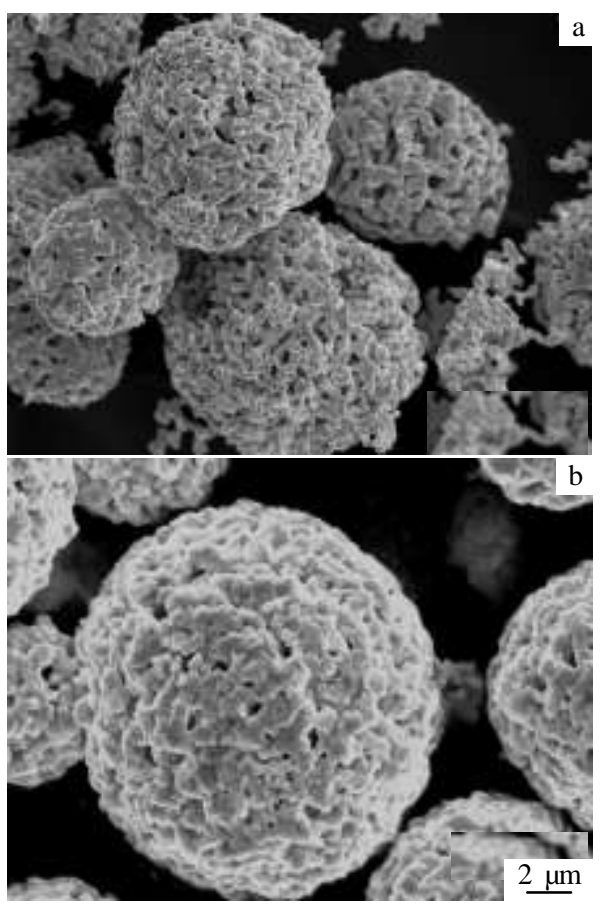

Fig.1 SEM images of WC-12Co powders: (a) nano-sized and (b) micron-sized

Table 1 AC-HVAF spraying parameters

\begin{tabular}{cc}
\hline Parameter & Value \\
\hline Propane pressure $/ \mathrm{kPa}$ & 448.16 \\
Powder feeder rotation $\mathrm{speed} / \mathrm{r} \cdot \mathrm{min}^{-1}$ & 8 \\
Spraying distance $/ \mathrm{mm}$ & 200 \\
\hline
\end{tabular}

A wide variety of mechanisms have been postulated for the formation of the WC-12Co phase structure. It is generally considered that the loss of carbon is due to its interaction of WC with the oxygen during spraying through thermal decomposition and oxidative decarburization. During the spraying process, the WC thermally decomposed into $\mathrm{W}_{2} \mathrm{C}$ and $\mathrm{C}$; then the oxidative decarburization happened along with the formation of $\mathrm{Co}_{6} \mathrm{~W}_{6} \mathrm{C}$ through the reaction of $\mathrm{W}_{2} \mathrm{C}$, $\mathrm{O}_{2}$ and metallic Co as shown in Eq (1).

$3 \mathrm{~W}_{2} \mathrm{C}+2 \mathrm{O}_{2}+6 \mathrm{Co}=\mathrm{Co}_{6} \mathrm{~W}_{6} \mathrm{C}+2 \mathrm{CO}_{2}$

\subsection{Microhardness of nano-sized WC-12Co coatings}

As shown in Fig.4, the average microhardness $\left(\mathrm{HV}_{0.3}\right)$ of AC-HVAF sprayed nano-sized WC-12Co coating reaches $19403 \mathrm{MPa}$ (standard deviation $456 \mathrm{MPa}$ ) on the as-sprayed surface and about $17410 \mathrm{MPa}$ (standard deviation $518 \mathrm{MPa}$ ) in the cross-section. Those of the micron-sized WC-12Co coatings are $16391 \mathrm{MPa}$ (standard deviation $766 \mathrm{MPa}$ ) on the as-sprayed surface and about $15112 \mathrm{MPa}$ (standard deviation $1412 \mathrm{MPa}$ ) in the cross-section. Nano-sized structure contributes to about 3000 $\mathrm{MPa}$ higher microhardness on the as-sprayed coating surface 


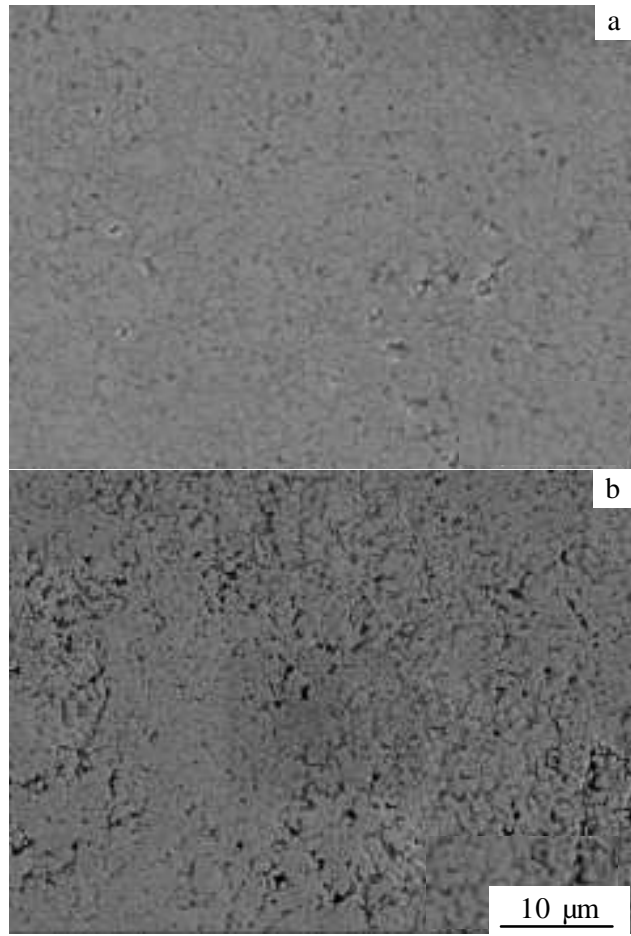

Fig.2 Cross sections of AC-HVAF sprayed WC-12Co coatings: (a) nano-sized and (b) micron-sized

and much smaller variance. Smaller WC particles filling the gaps among big ones enhance the consistency and density of the coating. These differences are related to the microstructure formed with flattened splats layer by layer. The cracks between layers make the coating much easier to be stretched than compressed along the direction perpendicular to the as sprayed surface. Thus, the microhardness difference could be another way of studying the cohesion in the sprayed coatings.

\subsection{Wear resistance of WC-12Co coatings}

The mechanical properties of $\mathrm{WC}$ grains are anisotropic because of the hexagonal lattice. When a WC grain is oriented with a prismatic plane parallel to the wear surface, wear occurs by the shear removal of thin platelets forming a smooth surface; when the basal plane is parallel to the surface, the grain cleaves along prismatic planes ${ }^{[8]}$. The wear resistance of thermally sprayed WC-12Co coatings is influenced by carbide size, carbon and cobalt contents, and porosity in the coating. For the conventional WC-12Co coating with micron size grains, its wear resistance increases with increasing WC grain size because large WC grains are held firmly by the binder phase so as not to be pulled out during the wear process. However, the wear resistance of nanocomposite does not follow this trend. The high wear resistance of nanostructured WC-12Co coatings can be attributed to their improved coating hardness,

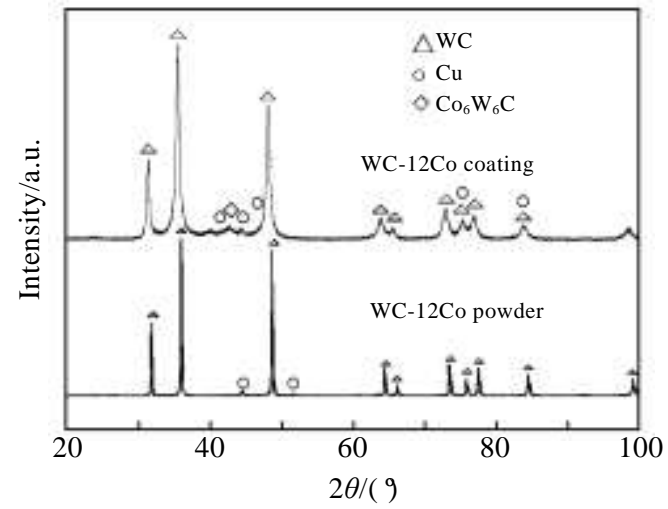

Fig.3 XRD patterns of nano-sized WC-12Co powders and coatings made by AC-HVAF
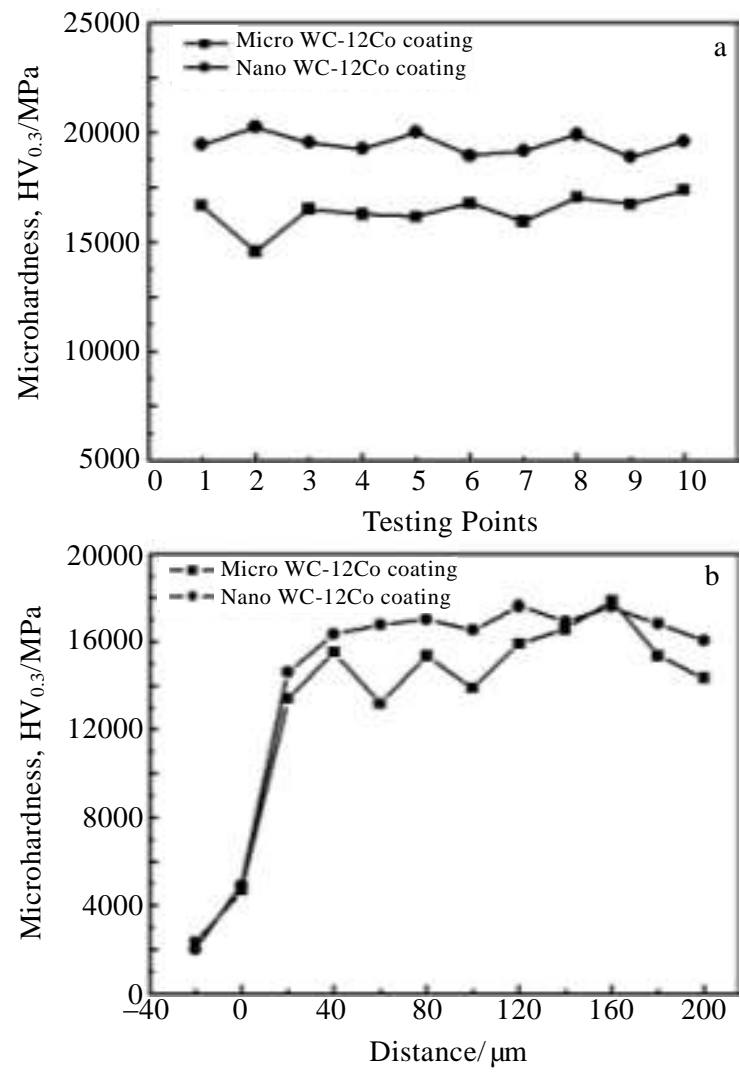

Fig.4 Microhardness of AC-HVAF sprayed WC-12Co coatings:

(a) sprayed surface and (b) cross-section

toughness and homogeneity, and the short mean free path of the cemented carbide will benefit to increasing WC-12Co hardness.

Fig.5 reveals that the nano-sized coatings possess very low mass loss during wear tests, which is nearly $40 \%$ lower than that of micron-sized coatings. Fig.6 shows the wear coefficients of coatings during dry friction testing in $30 \mathrm{~min}$ at a load of $15 \mathrm{~N}$ and rotational speed of $1198 \mathrm{r} / \mathrm{min}$ of $\mathrm{WC}$ 
counter body. The nano-sized coatings show a stable friction coefficient around 0.275 in the dry wear conditions, while the friction coefficient of micron-sized coatings fluctuates between $0.25 \sim 0.4$, which is the benefit of homogeneous distribution of nano-sized WC particles ${ }^{[9,10]}$. The wear coefficient is mainly affected by the properties of the two contact surfaces. While the nano-sized coating has higher surface smoothness and hardness, thus it will be much more difficult to bind together with its counter-body under the same testing conditions and it gets lower wear coefficient.

Fig.7 is the SEM micrographs of AC-HVAF sprayed nano-sized WC-12Co coatings after $30 \mathrm{~min}$ of dry friction tests. There is no large-scale coating layer peeling off, but a lot of small strips of various sizes around $10 \mu \mathrm{m}$ in the length direction are detected on the surface. Micro cracks initiate and propagate through the wear surface of coatings, and then cause coating layer spallation and/or delamination. The micro strip traces exhibit no large grooves and scratches, which indicates the homogeneously distributed nano-sized WC carbides greatly enhance the cohesion and bonding strength.

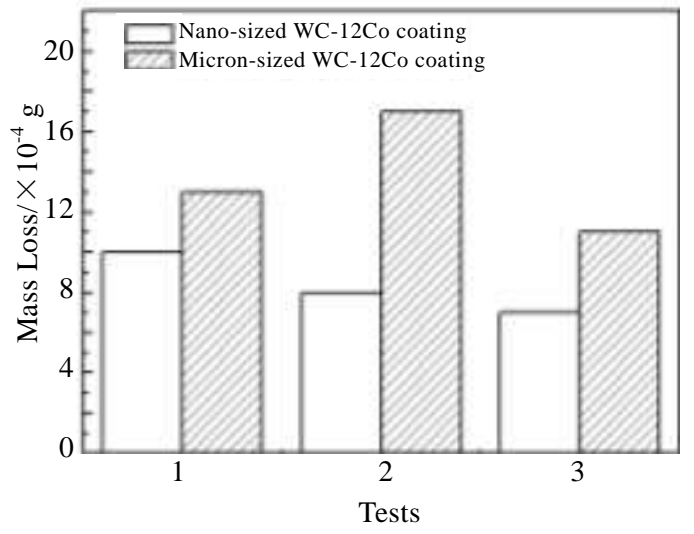

Fig.5 Wear mass loss of AC-HVAF sprayed WC-12Co coatings at a load of $15 \mathrm{~N}$ and rotational speed of $1198 \mathrm{r} / \mathrm{min}$ of WC counter body

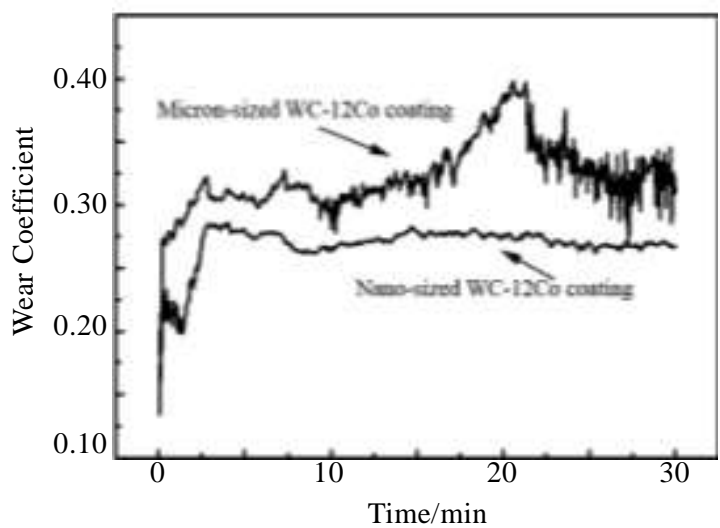

Fig.6 Wear coefficients of AC-HVAF sprayed WC-12Co coatings at a load of $15 \mathrm{~N}$ and rotational speed of 1198 $\mathrm{r} / \mathrm{min}$ of WC counter body

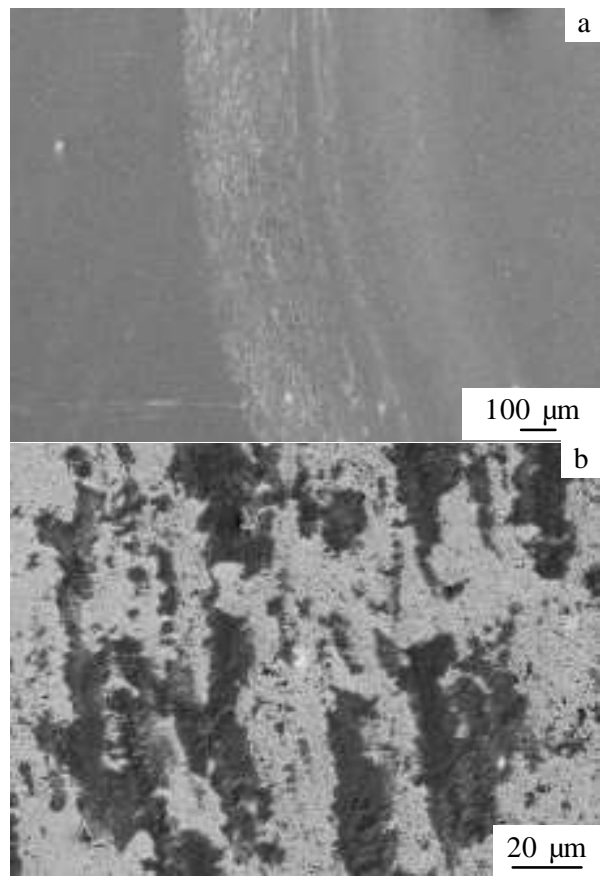

Fig.7 SEM micrographs of worn coating surface after $0.5 \mathrm{~h}$ testing at a load of $15 \mathrm{~N}$ and rotational speed of $1198 \mathrm{r} / \mathrm{min}$ of WC counter body: (a) low magnification and (b) high magnification

\section{Conclusions}

1) WC-12Co coatings with nano WC grain size of 80 100 $\mathrm{nm}$ are deposited by AC-HVAF system. The lower process temperature and weak oxidizing atmosphere contribute to the remaining of nano-sized WC.

2) The nano WC-12Co coating is lower than $1 \%$ in porosity and has an average microhardness as high as 19 $403 \mathrm{MPa}$ on the surface and $17410 \mathrm{MPa}$ on the cross-section.

3) At the load of $15 \mathrm{~N}$ and rotational speed of $1198 \mathrm{r} / \mathrm{min}$ of WC counter body, the mass loss is very low and the friction coefficient is around 0.275 in the dry wear conditions and the nano-sized WC-12Co coatings show higher and stable wear-resistant ability.

\section{References}

1 Pornthep Chivavibul, Makoto Watanabe, Seiji Kuroda et al. Surface and Coatings Technology[J], 2007, 202(3): 509

2 Kear B H, Skandan G, Sadangi R K. Scripta Materialia[J], 2001, 44(8-9): 1703

3 Wang Qun, Ding Zhangxiong, Chen Zhenhua et al. Journal of Hunan University, Natural Sciences[J], 2007, 34(2): 56 (in Chinese)

4 Jia K, Fischer T E, Gallois B. Nanostructured Materials[J], 
1998, 10(5): 875

5 Liu Shenglin, Sun Dongbai, Fan Zishuan et al. Surface and Coatings Technology[J], 2008, 202(20): 4893

6 Skandan Ganesh, Yao Ruvee, Kear Bernard H et al. Scripta Materialia[J], 2001, 44(8-9): 1699

7 Le Bourhis E, Rouxel T. Journal of Non-Crystalline Solids $[\mathrm{J}]$, 2003, 316(1): 153
8 Zhu Yingchun, Ken Yukimura, Ding Chuanxian et al. Thin Solid Films[J], 2001, 388(1-2): 277

9 Żórawski Wojciech. Surface and Coatings Technology[J], 2013, 220(15): 276

10 Wang Q, Chen Z H, Ding Z X. Tribology International $[\mathrm{J}]$, 2009, 42(7): 1046

\title{
AC-HVAF 喷涂纳米结构 WC-12Co 耐磨涂层的微观结构和性能
}

\author{
訤自拴, 王山松, 张正东 \\ (北京科技大学, 北京 100083)
}

\begin{abstract}
摘 要: 采用含纳米WC颗粒的WC-12Co粉末，通过空气助燃超音速火焰喷涂系统（AC-HVAF）制备了耐磨涂层。研究了涂层相组成、 微观结构、涂层硬度、断裂㓞性和耐磨损性能。X射线衍射分析结果表明WC为涂层主相, 未发现其他失碳分解产物。涂层孔隙率低于 $1 \%$, 晶粒尺寸为80 100 nm, 涂层磨光表面硬度 $\left(\mathrm{HV}_{0.3}\right)$ 高达19 $403 \mathrm{MPa}$, 横截面硬度高达 $17410 \mathrm{MPa}$ 。使用WC硬质球为摩擦副, 载荷 $15 \mathrm{~N}$, 工件转速 $1198 \mathrm{r} / \mathrm{min}$ 干磨条件下, 纳米结构涂层的平均失重比微米结构涂层降低 $40 \%$, 且纳米结构涂层摩擦系数为 $0.26 ~ 0.28$ (微 米结构涂层: 0.25 0.4), 因此纳米结构涂层具有更加优异的耐磨性能。
\end{abstract}

关键词: AC-HVAF; 纳米 WC; 显微硬度; 耐磨

作者简介：㚞自拴, 男, 1964 年生, 副教授, 北京科技大学材料科学与工程学院, 北京 100083, E-mail: fanzs5858@163.com 